\title{
BIODIESEL PRODUCTION FROM PALM FATTY ACID DISTILLATE (PFAD) USING REACTIVE DISTILLATION
}

\author{
Arief Budiman*, Alita Lelyana, Daniar Rianawati, and Sutijan \\ Chemical Engineering Department, Universitas Gadjah Mada, \\ Jalan Grafika 2 Yogyakarta 55281 Indonesia \\ Email: abudiman@chemeng.ugm.ac.id
}

\begin{abstract}
Palm fatty acid distillate (PFAD) is a lower-value by-product obtained during the refining of palm oil and contained high amount of free fatty acid (FFA). However, it's a potentially valuable and low-cost raw material for the production of biodiesel through esterification process. Esterification of FFA using the conventional batch faces a challenge since it is low in productivity and requires high excess of reactant so that it is not efficient for large-scale production. To overcome this problem, reactive distillation (RD) is the best candidate. RD is one of the most attractive equipment which provides potential benefits for the esterification reaction. To obtain an optimal design of the $\mathrm{RD}$, an accurate model and simulation of the process is needed. In this work, a simulation study of biodiesel production from PFAD as feedstock using RD is presented by using ASPEN Plus v7.1. Two case studies of total reflux (case A) and recycled distillate (case B) were demonstrated. Close relation was found among high separation and high energy consumption in RD. Two models of RD show the more economical heat duty of both condenser and reboiler. Effect of $\mathrm{L} / \mathrm{F}$ ratio, number of stages in reaction zone, and model of RD to conversion of esterification reaction were discussed.
\end{abstract}

Keywords: biodiesel, esterification, PFAD, reactive distillation

\begin{abstract}
Abstrak
Suatu produk hasil samping yang memiliki nilai ekonomi rendah, biasa dikenal sebagai Palm Fatty Acid Distilate (PFAD), diperoleh dari proses pemurnian minyak kelapa sawit. PFAD mengandung asam lemak bebas (FFA) tinggi, cukup potensial, dapat digunakan sebagai bahan baku produksi biodiesel melalui proses esterifikasi. Esterifikasi FFA dengan proses batch konvensional menghadapi tantangan karena produktivitasnya cukup rendah dan membutuhkan excess reaktan yang tinggi sehingga tidak efisien jika diterapkan untuk produksi skala besar. Reactive distillation (RD) dapat menjadi solusi untukmengatasi masalah ini. RD merupakan alat yang berpotensi memberikan keuntungan dalam reaksi esterifikasi. Untuk mendapatkan desain yang optimal dari suatu RD, pemodelan yang akurat dan simulasi dari proses ini diperlukan. Di sini, dilakukan simulasi produksi biodiesel dari PFAD menggunakan RD dilakukan dengan ASPEN Plus v7.1. Dua kasus dipelajari, yaitu refluks total (kasus A) dan recycle distillate (kasus B) yang bertujuan untuk mempelajari pengaruh rasio antara cairan yang dikembalikan ke kolom dengan feed (L/F), dan variable variable desain. Semakin tinggi kemurnian dari hasil pemisahan, konsumsi 101nergy yang dibutuhkan juga menjadi semakin besar. Perbandingan antara dua model dari kolom distilasi reaktif menunjukkan beban panas kondensor dan reboiler menjadi lebih ekonomis. Pengaruh perbandingan L/F, jumlah stage dalam zona reaksi, dan model kolom distilasi reaktif terhadap konversi reaksi esterifikasi akan di bahas di sini.
\end{abstract}

Kata kunci: biodiesel, esterifikasi, PFAD, menara distilasi

*Corresponding author 


\section{Introduction}

Biodiesel nowadays has become one of the developed emerging energy sources. Various innovations have been studied and some of them have been applied commercially in the manufacture of biodiesel, both the innovation of manufacturing technology and raw materials (Balat, 2010). The raw material of biodiesel production is currently more focused on nonedible oil to avoid interference with the stability of food if it uses edible oil. One of the potential raw materials is Palm Fatty Acid Distillate (PFAD), a by-product from palm oil refinery, which contains high amount of Free Fatty Acid (FFA) (Chongkong, 2007; Yujaroen, 2009). There are many advantages by using PFAD as the raw material of biodiesel production, such as not to disturb the stability of food, availability of relatively stable, and the price is relatively cheaper as compared to other vegetable oils. PFAD has been used in the soap-making industry as an animal feed ingredient, and as raw material for oleo-chemical industry. PFAD contains high FFA, with a small amount of unsaponifiable components and the remainder neutral oil (Santoso, 2008).

A conventional configuration for a process with chemical reactions involves two steps, chemical reaction in a reactor followed by separation step in a distillation column. In fact, both chemical reactions and separation by distillation can be carried out simultaneously. This combined unit operation is called reactive distillation. This configuration presents numerous advantages, such as improve conversion and selectivity, reduced catalyst requirement, and avoidance azeotrope. Since it combines reactor and distillation column in the same vessel, the most important benefit is

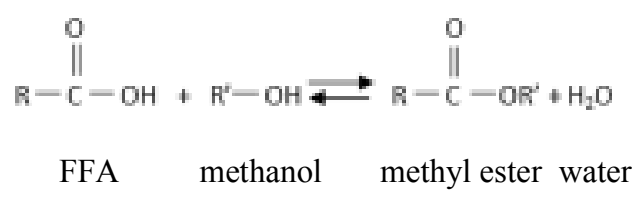

reduction in capital investment, plant operating cost and energy demand due to its heat integration (Doherty and Buyad, 1992).

Some works have been done mainly related to the chemical synthesis such as esterification processes of methyl or ethylacetate (Kloker, 2004; Venkataraman, 1990), MTBE (Budiman, 2006; Huang, 2008), propylene oxide (Bezzo et al, 1999), etc. Review of research, design, operation, scaleup and commercial application of this interesting area has been done by Harmsen (2007). While, some works have been done related to biodiesel production using reactive distillation such as biodiesel production from free fatty acid (An, 2009; Kusmiyati, 2008).

PFAD contains of $70-80 \%$ FFA (free fatty acid) and 20-30\% triglyceride. So, methyl ester (biodiesel) from PFAD is produced in two steps, i.e., esterification and trans-esterification reactions. The first step of the process is to reduce FFA with methanol and acid catalyst, while the second step is triglyceride portion reacts with methanol and base catalyst (Chongkong et al., 2007). Esterification and trans-esterification reaction is showed by Equation 1 and 2 .

We have discussed in detail transesterification of triglyceride of jatropha oil by continuous reactive distillation column (Budiman et al., 2009). So in this paper we concentrate on study of esterification reaction of PFAD.

The reaction kinetic of FFA in biodiesel production from PFAD catalyzed by sulfuric acid had been studied earlier (Lelyana, 2011). Based on the Arrhenius equation, the reaction kinetic showed by Equation 3 was found, where $k$ represents reaction kinetic $\left(\mathrm{min}^{-1}\right), R$ represents gas constant [J/ (mol.K)], and $T$ represents temperature $(\mathrm{K})$.

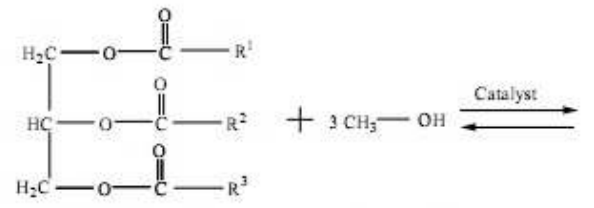

triglyceride

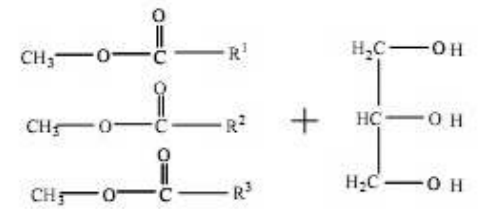

glycerol 


$$
k=1594.637 \theta^{\frac{33745.31}{\pi T}}
$$

Generally, there are two steps of biodiesel production. The first step is esterification, which produces alkyl ester from the reaction of FFA and methanol. The second one is trans-esterification, which produces alkyl ester and glycerol from the reaction of triglyceride and methanol. Besides these reactions, there is also a step to separate the biodiesel product from impurities. In conventional technology, the reaction and separation were done separately in different column or reactor (Mittelbach and Remschimidt, 2008). This conventional batch process faces a challenge since it is low in productivity and requires high excess of reactant (methanol) so that it is not efficient for large scale production.

In this work, a simulation study of biodiesel production from PFAD using reactive distillation is presented by using Aspen Plus v7.1. Two case studies of total reflux (Case A) and recycled distillate (Case B) were demonstrated to study the effect of reflux ratio and design variable, which is total number of stages in reaction zone, to the conversion of PFAD in esterification reaction. Then, the main parameter of reactive distillation using Aspen Plus v7.1 which is widely used for the flow sheet simulation in process industries, is analyzed and discussed comprehensively.

\section{Methodology}

Aspen Plus is one of standard process modeling tools for industrial simulation. This software is equipped with reliable thermodynamic data, realistic operating conditions and the rigorous equipment models, so it has capabilities to predict the actual behavior of a process using basic engineering relationships such as mass and energy balances, phase and chemical equilibrium, and reaction kinetics. The system is also supported by complete sets of modules, which includes reactive distillation where both reaction and separation are assumed to take place in the liquid phase in column trays or packing. In this work, we used ASPEN Plus v.71 to simulate esterification of PFAD using reactive distillation column.

The procedure of simulation on Aspen plus is as follows:

1. Flow-sheeting the reactive distillation process.

2. Defining components which are involved in esterification process, such as:

- FFA :palmitic acid, myristic acid, and stearic acid

- Triglyceride: triolein, tripalmitin, and tristearin.

- Methanol as reactant

- Sulfuric acid as catalyst

- Water as solvent of catalyst

3. Estimating the properties for components which are not available in data bank especially for triolein, tripalmitin and tristearin by inputting their molecular structure. NRTL property is assumed.

4. Using mixer and heater for preliminary process to get the best operational condition, and choosing RadFrac block for reactive distillation simulation.

5. Setting the operation conditions which are temperature, pressure, flow rate and composition for both feed and catalyst; specifying plate number, feed plate position, column pressure and distillate rate; and specifying reaction kinetic.

6. Running Aspen plus to analyze the sensitivity and characteristic of the main parameters.

The $101,49.06 \mathrm{~kg} / \mathrm{h}$ of PFAD contains $75 \%$-wt FFA (29.48 mol/h) and $25 \%$-wt triglyceride $(2.97 \mathrm{~mol} / \mathrm{h})$ is used as feed. Mass fraction of components in FFA are 0.88 palmitic acid, 0.02 myristic acid, and 0.09 stearic acid, while mass fraction of each components in triglyceride are 0.56 triolein, 0.36 tripalmitin, and 0.07 tristearin. That mixture introduced to the reactive distillation column (plate 3) along with $6794.45 \mathrm{~kg} / \mathrm{h}(212.32 \mathrm{~mol} / \mathrm{h})$ methanol that had been mixed with $135.88 \mathrm{~kg} / \mathrm{h}(1.38$ $\mathrm{mol} / \mathrm{h}$ ) sulfuric acid $98 \%$ as catalyst. We set pressure $0.9 \mathrm{~atm}$ (at the top), $1.1 \mathrm{~atm}$ (at the bottom) and distillate rate at $20 \mathrm{~mol} / \mathrm{h}$ for total reflux (Case A) and $185850 \mathrm{~mol} / \mathrm{h}$ for recycled distillate (Case B). A ten plate reactive distillation column including a total condenser (plate 1) and reboiler (plate 10) was used for Aspen simulation.

Figure 1 shows reactive distillation (RD) for biodiesel production from PFAD. Feed flows into reactive distillation column (RD 01) to react FFA with methanol and acid catalyst $\left(\mathrm{H}_{2} \mathrm{SO}_{4}\right)$. The mixture, then flows into RD 02 to react triglyceride with methanol and base catalyst $(\mathrm{KOH})$. Biodiesel resulted 


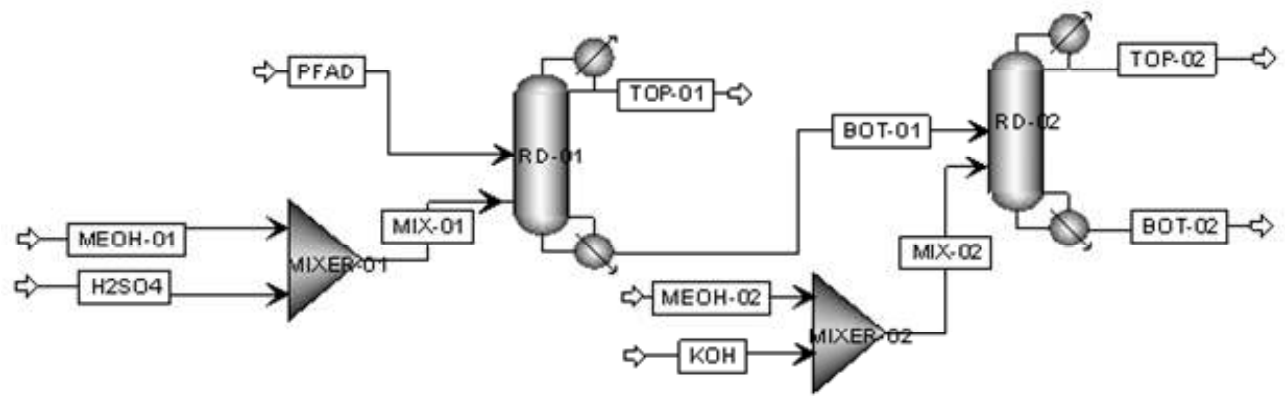

Figure 1. Reactive distillation (RD) for biodiesel production from PFAD

from esterification process in RD 01 and trans-esterification process in RD 02 then taken as bottom product.

Figure 2 shows configuration of reactive distillation with total reflux (Case A), where all the fluids from condenser are flowed back to column so that no distillate can be obtained. Figure 3 shows configuration of reactive distillation with recycled distillate (Case $B$ ), where stream from condenser is divided into liquid that flows back to column and distillate which is recycled and mixed with fresh methanol in feed.

\section{Result and Discussion}

Result from this study can be discussed by over viewing effect of L/F ratio, heat duty, and effect of design variables. We define reflux (L) to feed (F) ratio, L/F instead of reflux ratio. Here, $\mathrm{L}$ is the liquid condensed from the rising vapor on the top column which returns to the first column and $\mathrm{F}$ is for flow rate of feed.

\subsection{Effect of L/F Ratio}

Figures 4 and 5 show the simulation results of relationship between $\mathrm{L} / \mathrm{F}$ ratio and mol fraction for Case A (total reflux) and Case B (recycled distillate), respectively. From these figures, we may see that mol fraction of products, i.e., methyl ester (biodiesel) and water increase with the increasing of $\mathrm{L} / \mathrm{F}$ ratio for both Cases A and B. On the contrary, PFAD and methanol inputted to the column decrease with the increasing of $L / F$ ratio.

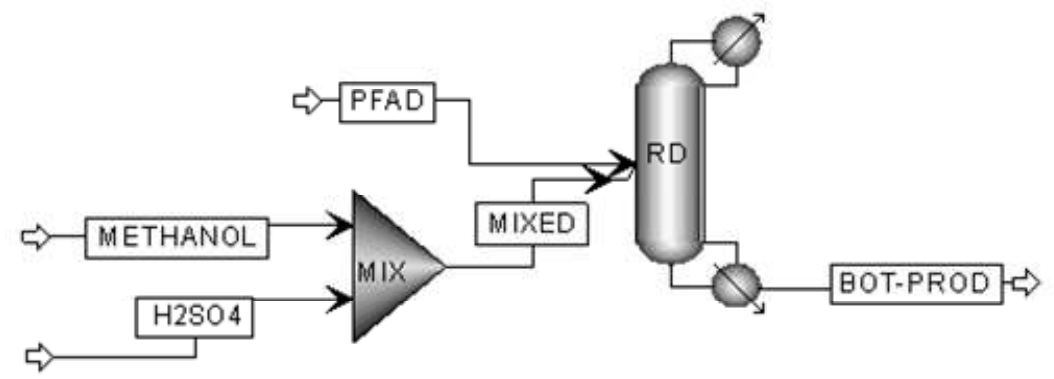

Figure 2. RD for esterification of PFAD with total reflux (Case A)

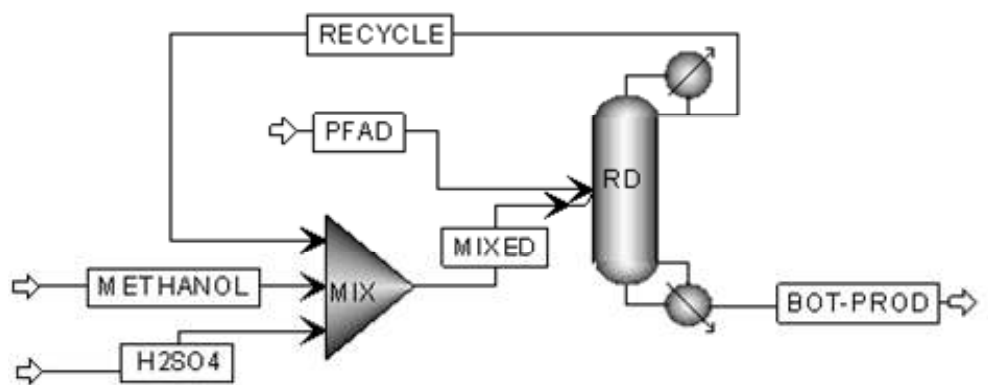

Figure 3. RD for esterification of PFAD with recycled distillate (Case B) 


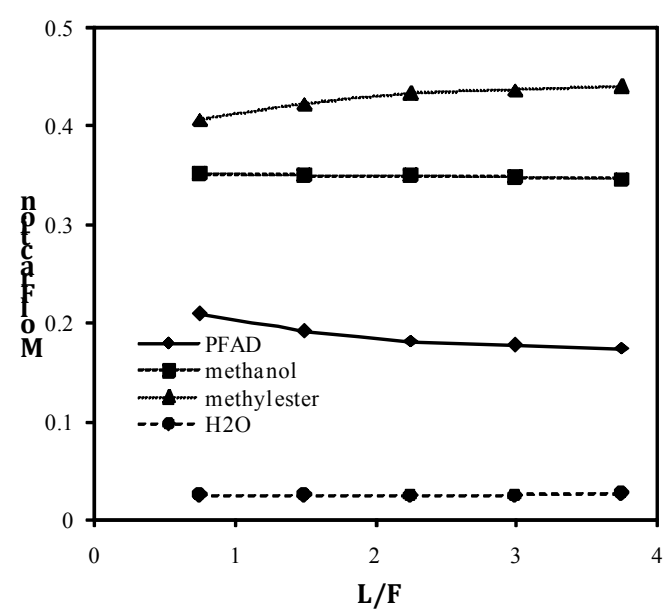

Figure 4. Reflux ratio-mol fraction for case $A$

The increasing of product's fraction in line with the increasing of $\mathrm{L} / \mathrm{F}$ ratio of case $\mathrm{A}$ and $B$ because of the existence of reflux and recycle distillate streams will increase reaction effectiveness. About the conversion, there is no significant difference between conversion of case A and B. That is because component involved during reaction is the same. But based on the process, conversion of case B is a little higher than conversion of case $A$ because trajectory path of methanol in reactive column for case $B$ is longer than for case A.

Figures 6 and 7 show the simulations result of relationship between $\mathrm{L} / \mathrm{F}$ ratio and conversion for Cases A and B, respectively. From these figures we may denote that the conversion of PFAD increases with the increasing of $\mathrm{L} / \mathrm{F}$ ratio. The increasing of $\mathrm{L} / \mathrm{F}$

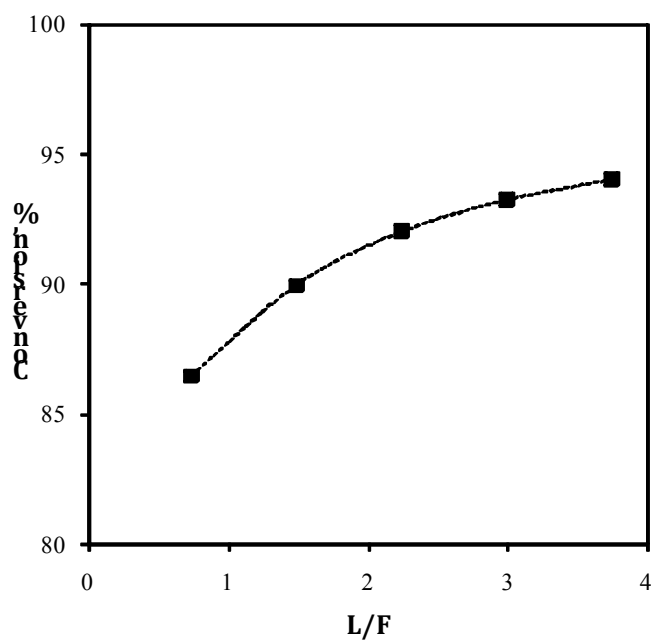

Figure 6. Reflux ratio-mol fraction for case A

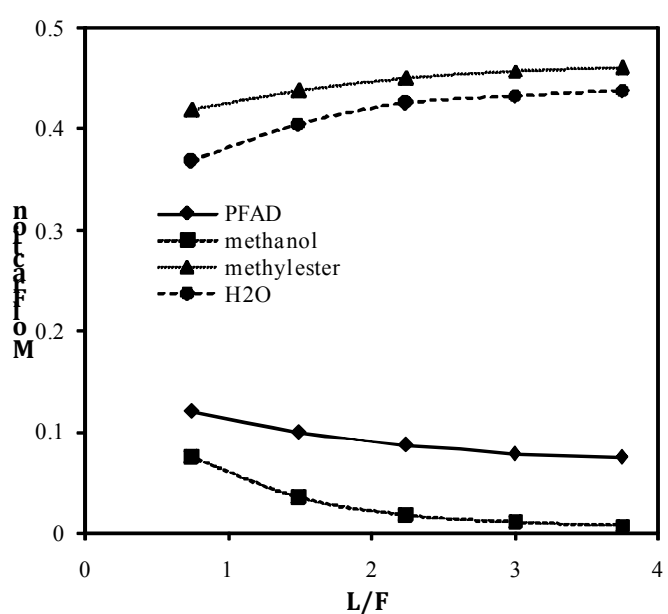

Figure 5. Reflux ratio-mol fraction for case $B$

ratio means liquids have longer time to react inside the column, so that the conversion of PFAD becomes higher. The highest conversion of both cases is almost the same. Thus, it can be concluded that $\mathrm{L} / \mathrm{F}$ ratio does not give significant effect to the conversion of PFAD.

\subsection{Heat Duty}

Figures 8 and 9 show the simulation result of relationship between $\mathrm{L} / \mathrm{F}$ ratio and heat duty for case Case A (total reflux) and Case B (recycled distillate), respectively. From these figures, shown that the heat duty of condenser and reboiler increase with the increasing of $\mathrm{L} / \mathrm{F}$ ratio. By increasing $\mathrm{L} / \mathrm{F}$ ratio, total fluids flowing in the column are in bigger amount, so that the heat needed in condenser and reboiler is also larger.

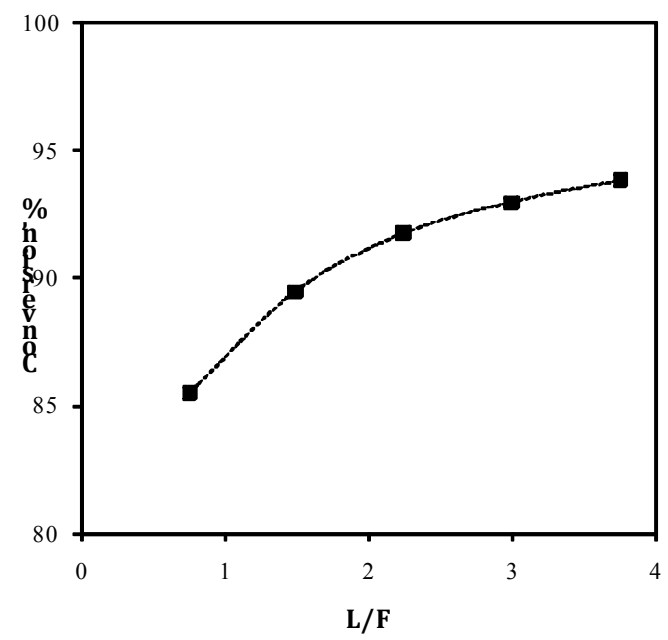

Figure 7. Reflux ratio-mol fraction for case B 


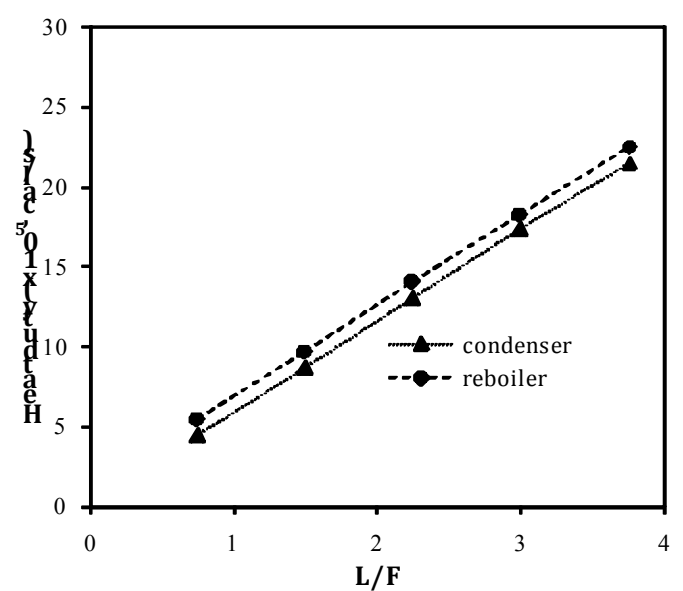

Figure 8. L/F ratio-heat duty diagram for case $A$

However, the heat duty of condenser and reboiler for Case B is higher than that the heat duty for Case A. This might be caused in case $\mathrm{B}$, in order to adjust temperature of distillate before recycling it to the feed, additional heat duty is needed. Thus, it can be concluded that total reflux model (Case A) gives the more economical heat duty of condenser and reboiler.

\subsection{Effect of Design Variables}

Generally, in reactive distillation, the column is divided into 3 sections, i.e., rectifying, reaction, and stripping sections. In rectifying section, lighter components are being enriched and heavier components removed. This is in contrast to the stripping section where the lighter components are being stripped out of the bottom product and the heavier components consequently concentrated. While reaction take places in reaction section on a trays or zone filled with packing.

Two case studies of $\mathrm{A}$ and $\mathrm{B}$ demonstrated to study the influence of total number of stages used for reaction (reaction zone) on conversion, shown in Figure 10. This is caused by the fact that increasing of total number of stages used for reaction resulting contact area and time for reaction of FFA from PFAD and activated methanol is getting larger.

Comparison of Cases A and B, they can be seen that conversion of reaction achieved by reactive distillation with recycled distillate (Case B) is higher than that achieved by reactive distillation with total reflux (Case A) when using the same total

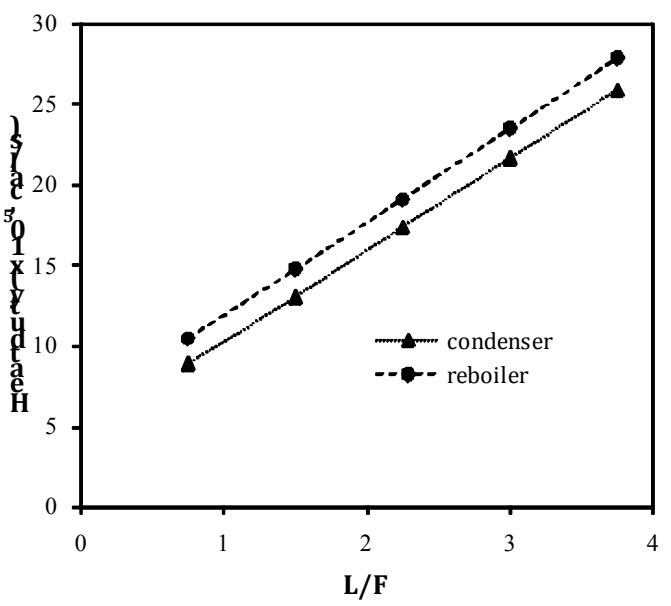

Figure 9. L/F ratio-heat duty diagram for case B

number of reaction zone, even though the difference is not significant.

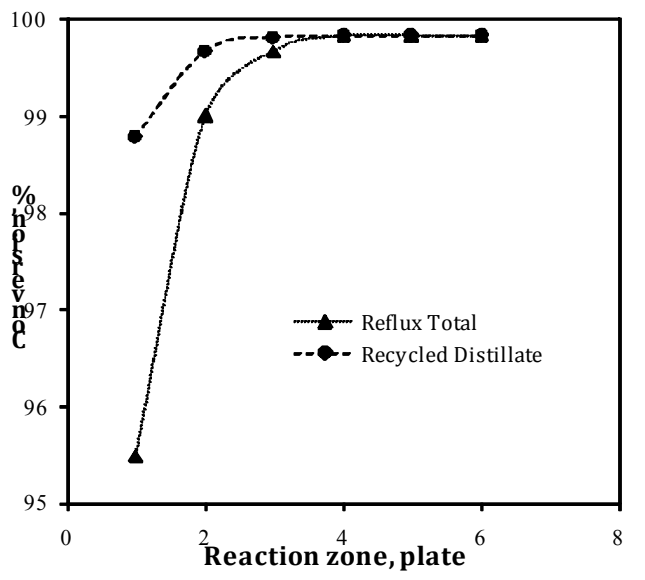

Figure 10. Reactive zone conversion diagram

The lower of conversion for Case A might be caused by larger amount of the methanol flowed to the bottom of column and carried out with the bottom product than that for Case B. Here, for Case B, methanol obtained in distillate was recycled so that methanol that ready to react in the column is relatively larger.

\section{Conclusions}

In brief, we can conclude that esterification via reactive distillation column can be simulated by ASPEN Plus v7.1. Ratio of $\mathrm{L} / \mathrm{F}$ does not give significant effect to the conversion of PFAD. In comparison between two models, total reflux model gives the more economical heat duty of condenser, and reboiler than that of recycled distillate. 
Besides, conversion increased with the increasing of total number of stages in reaction zone, and conversion achieved by reactive distillation with recycled distillate is higher than that of total reflux when using the same stage in reaction zone. Similar works can be conducted for other design variables in the future.

\section{References}

An, K. C. C., Simulation of Heterogeneously Catalysed Esterification for The Biodiesel Production Using Reactive Distillation Column, Report, Chemical and Natural Resources Engineering, Faculty of Universiti Malaysia Pahang, Pahang, 2009.

Balat, M; Balat, H., Progress in biodiesel processing, Applied Energy, 2010, 87(6), 1815-1835.

Bezzo, F.; Bertucco, A.; Forlin, A.; Barolo, M., Steady-state analysis of industrial reactive distillation column, Separation and Purification Technology, 1996, 16(3), 251260.

Budiman, A.; Kusumaningtyas, R. D.; Sutijan; Rochmadi; Purwono, S., Second generation of biodiesel production from indonesia jatropha oil by continuous reactive distillation process, Asean Journal of Chemical Engineering, 2009, 9(2), 35-48.

Budiman, A.; Sutijan, Umul, K.; Risal, R., Separation Performance of Reactive Distillation Column: Case study in Methyl Tertier Butyl Eter (Indonesia), National Conference of Indonesia's Chemical Engineers, Yogyakarta, February 2006.

Chongkong, $\quad$ S.; $\quad$ Tongurai, $\quad$ C.; Chetpattananondh, P.; Bunyakan, C., Biodiesel production by esterification of palm fatty acid distillate, Biomass and Bioenergy, 2007, 31(8), 563-568.
Doherty, M. F.; Buzad, G., Reactive distillation by design, Chemical Engineering Research \& Design, 1992, 70(A5), 448-458.

Harmsen, G. J., Reactive distillation: The front-runner of industrial process intensification: A full review of commercial applications, research, scale-up, design and operation, Chemical Engineering and Processing: Process Intensification, 2007, 46(9), 774-780.

Huang, K.; Wang, S. J.; Ding, W., Toward further internal heat integration in design of reactive distillation column--Part III: Application to a MTBE reactive distillation column, Chemical Engineering Science, 2008, 63(8), 2119-2134.

Kusmiyati, Reaksi katalitis esterifikasi asam oleat dan metanol menjadi biodiesel dengan metode distilasi reaktif, Reaktor, 2008, 12(2), 78-82.

Lelyana, A., Kinetics Study of Biodiesel Synthesis from Palm Fatty Acid Distillate, Research Report, Chemical Engineering Universitas Gajah Mada, September 2011.

Mittelbach, M.; Remschmidt, C., Biodiesel: The Comprehensive Handbook, $1^{\text {st }}$ Ed., Boersedruck Ges.m.b.H: Vienna, Austria, 2008.

Santoso, S. J., Palm oil boom in indonesia: from plantation to downstream products and biodiesel, CLEAN - Soil, Air, Water, 2008, 36(5-6), 453-465.

Venkataraman, S.; Chan, W. K.; Boston, J. F., Reactive distillation using ASPEN PLUS, Chemical Engineering Progress, 1990, 86(8), 45-54.

Yujaroen, D.; Goto, M.; Sasaki, M.; Shotipruk, A., Esterification of palm fatty acid distillate (PFAD) in supercritical methanol: Effect of hydrolysis on reaction reactivity, Fuel, 2009, 88(10), 2011-2016. 